\title{
Covid-19, Emergency Laws and Enforcement in Nigeria: An Appraisal
}

\author{
Akujobi Alero. T. \\ Ph.D., Associate Professor, National Open University of Nigeria
}

\begin{abstract}
The essence of the paper is to examine the Infectious Diseases laws and the Nigerian Quarantine Act of 1926 and see if the laws cover the COVID-19 pandemic like the Spanish fluid, Ebola etc. Also, whether other eminent laws are required to mitigate deficiencies in the existing laws. The emergency laws and COVID-19: guidelines (law enforcement) will also be analyzed. In a nutshell, the legal analysis of relevant emergency legislation and/or jurisprudence as it is applicable to principal controls and compliance proposed by World Health Organisation and member countries for the monitoring, control and administration of the disease will be examined. The enforcement of the emergency rules and laws and its impact on human rights violations will equally be x-rayed with a view to recommend mitigations and solutions. This paper concludes by advocating a health law that will cater for health emergencies and aligning with best world health practices for Nigeria
\end{abstract}

Keywords: Covid-19, Nigeria, emergency, laws, enforcement

DOI: $10.7176 / \mathrm{JLPG} / 105-04$

Publication date: January $31^{\text {st }} 2021$

\section{Introduction}

Coronavirus disease called COVID-19 is an infectious disease like every other infectious disease that has existed before now. Coronavirus disease is caused by a newly discovered virus in the year 2019 and was named after the year of its occurrence as COVID-19. Furthermore, it is referred to as COVID-19 pandemic because of its widespread nature from nation to nation as a result of movement of people.

Most people infected with the COVID-19 virus will experience mild to moderate respiratory illness and recover without requiring special treatment or a combination of medication on trial. COVID-19 is mainly transmitted through droplets generated when an infected person coughs, sneezes, or exhales the virus. These droplets are too heavy to hang in the air, and quickly fall on floors or surfaces. ${ }^{1}$ You can be infected by breathing in the virus if you are within proximity of someone who has the disease, or by touching a contaminated surface and the eyes, nose or mouth are medium of exchange of this disease. ${ }^{2}$ The best way to prevent and slow down transmission is to be well informed about the virus, the causes and how it spreads.

Immediate WHO recommendation for prevention and control is by washing your hands or using an alcoholbased sanitizer frequently and avoid touching your face. Upon the discovery and confirmation of this notable disease by World Health Organisation (W.H.O), an immediate notification was passed to member countries, preliminary precautions and conditions were laid out for both people and countries to follow and comply to save lives and avoid spread of the disease. This appears to be the first rule of law or regulations on COVID-19.

Historically, this Coronavirus emerged in Wuhan, China between October and December 2019 and spread to other countries and nations due to movement of infected people. Before $11^{\text {th }}$ March 2020, this virus was viewed as normal politics played among the Group of Eight Countries (G8) world powers and World Health Organisation (WHO). WHO announced COVID-19 outbreak as a pandemic on this date and a set of rules were announced to be followed by people and nations. After the Spanish influenza in 1918 - 1920, other infectious diseases have been local or at worst among few counties within a nation and has been easy to control and manage without affecting the entire world. $\mathrm{WHO}^{3}$ at its initial announcement marshalled out eights (8) rules for guiding the spread and control of the disease, without analysing how effective these rules will be.

These rules are: -

- Regularly clean your hands with an alcohol-based hand rub or wash them with soap and water.

- Maintain at least 1 metre (3 feet) distance between yourself and others.

- Avoid crowded places.

- Avoid touching eyes, nose and mouth.

- Good respiratory hygiene.

- Stay home and self-isolate when infected.

- If you have a fever, cough and difficulty breathing, seek medical attention from your local authority.

\footnotetext{
${ }^{1}$ Nigerian Centre for Disease Control and Prevention Act 2018 (NCDC) statement in March 2020.

${ }^{2}$ As item 1 above

${ }^{3}$ World Health Organisation Dashboard; available at: https://www.who.int/emergencies/diseases/novel-coronavirus-2019/advice-for-public assessed 24th September 2020; accessed $3^{\text {rd }}$ August 2020.
} 
- $\quad$ Keep up to date on the latest information from trusted sources (WHO and your local authority).

These monsters called rules then became the underlying guiding principles for countries. Countries emergency laws further created hydra headed monsters that took control of the world and led to global lockdown, paralysed world economic activities and created a 'new normal' for human existence. It is the intent of this paper to view how this new normal interrelate with existing laws, and challenges it posed.

Due to the uncertainty and nature of this virus, presidents and parliaments of different countries relied on their respective constitutional emergency provisions to address and set up parallel and special laws to address the pandemic. Countries had to set up special task forces to address and handle the virus. However, it was observed that these emergency rules and laws trampled upon human rights. The human rights ${ }^{1}$ are:

- The right to equality and freedom from discrimination

- $\quad$ The right to life, liberty, and personal security

- Freedom from torture and degrading treatment

- The right to equality before the law

- The right to a fair trial

- The right to privacy

- Freedom of belief and religion

- Freedom of opinion

\section{Covid-19 and Problems Encountered}

First, the virus was known in 2019 and World Health Organisation, in addition to its numerous roles, monitored the infectious disease, warned and proffer solutions and remedy to ensure member nations benefit; it announced the virus as a pandemic in $11^{\text {th }}$ March 2020. This information and announcement came late as the virus had spread to other countries and nations due to movement of infected people. The second problem was the emergency laws and enforcement by various countries that were not consistent or harmonized as it is a global issue, thereby impacting on both human rights and countries' border relationships. These rules and laws created panic in the world leading to world economy collapse and lockdown in many countries. Third issue is the creation of "new normal", which citizens are yet to adapt and comprehend.

The first report of this disease met Nigeria unprepared because while other nations immediately locked down and closed borders to contain the virus, there was confusion as to how and what laws should be applied. The initial challenge was the Nigerian Centre for Disease Control (NCDC) committee, which relied on the powers of the President in the Nigerian 1999 Constitution. Before now, on 12 ${ }^{\text {th }}$ November 2018 the Nigerian Centre for Disease Control and Prevention was established with powers to deal with infectious disease rather than using the Nigerian Quarantine Act of 1926. This created issues and people became worried as different interpretations were given between the 1999 Constitution, the guiding rules of NCDC and the Nigerian Quarantine Act of 1926. The Act was referenced in the Constitution with no elaboration. ${ }^{2}$ Finally, on $29^{\text {th }}$ March 2020, the President relied on the rules under the Quarantine Act of 1926 law, which allows the President to declare a place within the country an infected local area. This declaration nailed the highly controversial issues but still left legal questions on emergency laws and enforcements hanging.

\section{Overview of Emergency Laws and Covid-19 Guidelines}

The objective of this paper is to review the emergency laws and enforcement and their impact on human rights in Nigeria. Before now, Nigeria had several Acts that tend to deal with infectious diseases with no harmonization. These Acts are, the Nigerian Quarantine Act, ${ }^{3}$ Nigeria Centre for Diseases Control and Prevention Act ${ }^{4}$ and the Nigerian Constitution..$^{5}$ Upon the setup of the emergency NCDC committee by the President, these three laws were $\mathrm{X}$-rayed with learner mindset as to which is more appropriate to deal with the Coronavirus pandemic. The process and setting of the Special Task Force became subject of critics by human right activist and legal luminary. Also was the issue of whether all these Acts be married in dealing with the pandemic or not, not minding the human right violations

Before going further, it is important to elucidate on NCDC. The Nigerian Centre for Disease Control ${ }^{6}$ outdid the powers of the country's national public health institute, because, the NCDC mandate was to oversee the preparedness, detection and response to infectious disease outbreaks and public health emergencies. NCDC was established in 2011 under the departments in the Ministry of Health, including the Epidemiology Division, the

\footnotetext{
${ }^{1}$ Human Rights; available at: https://www.ohchr.org/EN/Issues/ESCR/Pages/Whatareexamplesofviolations of ESCR.aspx; accessed 5 ${ }^{\text {th }}$ August 2020.

${ }^{2}$ See section 305 of the Nigerian Constitution (as amended)

${ }^{3}$ The Nigerian Quarantine Act 1926.

${ }^{4}$ Act no. 18 dated $12^{\text {th }}$ November 2018 establishing Nigerian Centre for Disease Control and Prevention.

${ }^{5}$ The 1999 Nigerian constitution as amended.

${ }^{6}$ https://ncdc.gov.ng/ncdc; Accessed $7^{\text {th }}$ August 2020.
} 
Avian Influenza Project and its laboratories. The Nigeria Field Epidemiology and Laboratory Training Programme (NFELTP) were created to form the nucleus of the agency. ${ }^{1}$

The task of NCDC is 'to protect the health of Nigerians through evidence-based prevention, integrated disease surveillance and response activities, using a one health approach, guided by research and led by a skilled workforce'.

The core functions of NCDC are:

- $\quad$ Prevent, detect, and control diseases of public health importance.

- Coordinate surveillance systems to collect, analyze and interpret data on diseases of public health importance.

- Support States in responding to small outbreaks and lead the response to large disease outbreaks.

- Develop and maintain a network of reference and specialized laboratories.

- $\quad$ Conduct, collate, synthesize and disseminate public health research to inform policy.

- Lead Nigeria's engagement with the international community on diseases of public health relevance.

Suffice to say that NCDC is structured under a Director General and six Directorates, four of which are Technical Directorates. The body is made up of:

- $\quad$ Public Health Laboratory Services

- Prevention Programmes and Knowledge Management

- $\quad$ Emergency Preparedness and Response

- $\quad$ Surveillance and Epidemiology

- Finance and Accounts

- Administration and Human Resources

In appointing the task force, the President, under the Emergency Act nominated a chairman and some of the Federal Executive Council members to join the NCDC members and asked the Secretary to the Government of the Federal Republic of Nigeria to lead this unprecedented committee. This was against the principles setting up NCDC. The core functions of the NCDC include: Prevent, detect, and control diseases of public health importance. Coordinate surveillance systems to collect, analyze and interpret data on diseases of public health importance. It also supports States in responding to small outbreaks and lead the response to large disease outbreaks.

This emergency committee of the NCDC had to put up ten guidelines, ${ }^{2}$ many of which impacted on human rights. The ten guidelines are:

- COVID-19 discharge Policy 24.06.2020: The revised discharge policy is aligned with the guidelines on the three tier COVID facilities and the categorization of the patients based on clinical severity available. ${ }^{3}$

- $\quad$ CPCB Guidelines for disposal of COVID-19 19.04.2020; Guideline for treating, handling and disposal of waste generated during treatment/diagnosis/quarantine of COVID-19 patients. $^{4}$

- Revised guidelines quarantine facilities NCDC 24.04.2020: Quarantine is the separation and restriction of movement or activities of persons who are not ill but who are believed to have been exposed to infection, for the purpose of preventing transmission of disease. Persons are usually quarantined in their homes, but they may also be quarantined in community-based facilities. ${ }^{5}$

- Roles and Responsibilities of Rapid Response Teams (RRTs) in COVID-19 responses; composition of central RRTs are epidemiologist, microbiologist and any other person deployed as per need. Members of the central RRT will work in close coordination with state and district RRTs both at central and local levels. ${ }^{6}$

- Guidelines to be followed on detection of suspects or confirmed COVID-19 cases. ${ }^{7}$ Actions to be taken on detection of suspect/confirmed COVID-19 case in a healthcare facility.

- Home Quarantine Guidelines EMR division; ${ }^{8}$ Detection of a travel related/unrelated suspect case of novel Coronavirus Disease (COVID-19) will be followed by rapid isolation of such cases in designated health facilities and line listing of all contacts of such cases. Home quarantine is applicable to all such contacts of a suspect or confirmed case of COVID-19.

- Model Micro plan for containment of local transmission of COVID-19. ${ }^{9}$ The containment zone will be decided by the RRT based on the extent of cases/contacts listed and mapped by them.

\footnotetext{
${ }^{1}$ The Bill for an Act to establish NCDC was signed into law in November 2018.

${ }^{2} \mathrm{https}: / /$ www.ncdc.gov.in/index1.php?lang=1\&level=1\&sublinkid=703\&lid=550 Accessed on $14^{\text {th }}$ August 2020.

${ }^{3} \mathrm{https}: / /$ www.mohfw.gov.in/pdf/FinalGuidanceonMangaementofCovidcasesversion2.pdf): Accessed on $14^{\text {th }}$ August 2020.

${ }^{4}$ https://www.ncdc.gov.in/showfile.php?lid=551: Accessed on $16^{\text {th }}$ August 2020.

${ }^{5} \mathrm{https}$ ://www.ncdc.gov.in/showfile.php?lid=552: Accessed on $17^{\text {th }}$ August 2020.

${ }^{6} \mathrm{https}: / /$ www.ncdc.gov.in/showfile.php?lid=523: Accessed on $17^{\text {th }}$ August 2020

${ }^{7}$ https://www.ncdc.gov.in/showfile.php?lid=553: Accessed on $17^{\text {th }}$ August 2020.

${ }^{8} \mathrm{https}: / /$ www.ncdc.gov.in/showfile.php?lid=555: Accessed on $17^{\text {th }}$ August 2020.

${ }^{9}$ https://www.ncdc.gov.in/showfile.php?lid=529: Accessed on $17^{\text {th }}$ August 2020.
} 
- Home care guidelines for 2019-nCoV. ${ }^{1}$ Any person(s) suggestive of 2019-nCoV, should be confined at home for a period of 14 days and avoid close contact with public and other members in the family.

- Guidelines on clinical management of severe acute respiratory illness converted. ${ }^{2}$ Clinicians taking care of hospitalized adult and paediatric patients with severe acute respiratory infection (SARI) when an $\mathrm{nCoV}$ infection is suspected

- Guideline for workplace of COVID-19. ${ }^{3}$ Someone who has COVID-19 coughs or exhales, they release droplets of infected fluid. Most of these droplets fall on nearby surfaces and objects - such as desks, tables or telephones. People could catch COVID-19 by touching contaminated surfaces or objects - and then touching their eyes, nose or mouth.

Beyond above guidelines, the following were also put in place, total boarder lockdown (interstate, national and international) and a stop of social and economic activity, except those activities relating to essential services. Both police, paramilitary and the armed forces were used to checkmate movement of people, restrictions and compliance to COVID-19 guidelines. These measures strangled existing public health advisories. These raised significant legal, constitutional and human rights issues. While blocking roads both within state and interstate, people's rights were heavily infringed by the unguided uses of forces as if war is declared.

Palliatives were initiated and both individuals and State governments were encouraged to sustain citizens without adequate plans, the lockdown period became prolonged and the duration unknown. There was no available demographic data to guide the government resulting in few individuals getting the palliatives. More saddening was the fact that the needy were disenfranchised leaving an unprecedented situation. Furthermore, the rights of the needy were infringed upon as many were assaulted during the sharing of the palliatives by the law enforcement agents The Minister of Communications was reported to have said that the poorest of the poor in the country were identified and offered supports through the SIM registration data mined by the ministry. ${ }^{4}$ This is a gross violation of the right to privacy and data protection in Nigeria, as data protection regulation is not in place. It is worth noting that the Nigerian Constitution provides for the right to privacy in section $37,{ }^{5}$ the right to data protection can only be indirectly implied in this section.

The following human rights were badly impacted,

- The right to equality and freedom from discrimination - COVID patients' isolation issues cases.

- The right to life, liberty, and personal security - lockdown at home (Movement restrictions).

- Freedom from torture and degrading treatment - violations of lockdown were punished.

- The right to equality before the law - Parallel laws existence.

- The right to a fair trial - COVID-19 enforcement laws.

- The right to privacy - Restrictive laws (prison syndrome existed).

- Freedom of belief and religion - Religious restrictions rules.

- Freedom of opinion - Emergency Restriction rules.

The 1999 Constitution in effect accorded the President of Nigeria the power to declare an emergency where there is imminent danger or disaster or natural calamity affecting a community, or any other public danger constituting a threat to the country. Declaration of an emergency in this case would require the ratification by the National Assembly after the President's proclamation otherwise such a proclamation would expire in 10 days. ${ }^{6}$

Notwithstanding the above, the President decided a different approach to impose restrictions. Instead of passing a proclamation of emergency, which would have required the input of the National Assembly, he issued rules under the Quarantine Act, of 1926 law, which allows the President to declare a place within the country an infected local area. In line with the Quarantine Act, States can only make guidelines where the President fails to do so. However, it is also important to highlight that quarantine and labour are exclusive matters under the Constitution, and only the Federal Government has the authority to make laws relating to them. This meant that, that States cannot make guidelines where the President had done so, and if states had already passed rules, such cases would cease to exist or become invalid.

In the midst of the confusion, some States passed rules and executive orders that restricted entry and prohibited work except essential services, and imposed penalties, thus violating the rights of persons to movement and to other rights. Some of these matters were brought before the courts, and decisions were hazily taken against the culprit with fines and in other cases, community service was imposed on offenders. ${ }^{7}$

\footnotetext{
${ }^{1}$ https://www.ncdc.gov.in/showfile.php?lid=462: Accessed on $17^{\text {th }}$ August 2020.

${ }^{2}$ https://www.ncdc.gov.in/showfile.php?lid=458: Accessed on $17^{\text {th }}$ August 2020 .

${ }^{3}$ https://www.ncdc.gov.in/showfile.php?lid=495: Accessed on $17^{\text {th }}$ August 2020.

${ }^{4} \mathrm{On} 24^{\text {th }}$ April 2020, Olugbenga Adani reporter for International Centre for Investigative Reporting (ICIR) reported Isa Pantami- Minister of Communication - COVID-19: Controversy trails Ministers' decision to mine data of phone users without consent.

${ }^{5}$ Chapter IV, Fundamental Rights of 1999 Constitution as amended.

${ }^{6}$ Section 305 sub-section 4 (b) of 1999 Nigerian Constitution.

${ }^{7}$ The case of Nigerian entertainer Funke Akindele and her husband who were convicted for having a party involving the gathering of over fifty persons and in which social distancing was not observed which was clearly against the COVID-19 regulations.
} 
At the beginning, there were deceptive opinion and public acceptance on the restrictions of the COVID-19 Regulations, and this led to a notch of compliance because of fear. The manner of enforcement of the restrictions in several states around the country led to reports of human rights abuses. These included killing of over seventeen ${ }^{1}$ people by law enforcement agents, confinement without court orders in places where physical distancing ${ }^{2}$ was impossible, demolition of a hotel in River State, and deportation ${ }^{3}$ of young children under the name of beggars on the northern Nigeria streets. These children rights were infringed as well as their socio-economic rights under Nigerian law.

These regulations under this pandemic were felt in all sectors of Nigerian economy, the country has a large informal sector and people who survive on daily basis suffered most. With a limited welfare system in Nigeria, the government was unable to provide enough support, which raised displeasure and doubt among people. Furthermore, this impacted the poor mostly and also led to people coming out to beg for food in many cities. There were cases of sexual and gender ${ }^{4}$ cruelty, and disabilities ${ }^{5}$ people moved from State to State at nights in search of where to beg for food or where palliatives are being shared. Eminent unrest became visible and this may be the major reason for the early easement on restrictions, while the country still had a high number of cases of COVID19. Nigeria's daily statistics across the country showed rise in the curve during this period, rather than flatten as required by WHO.

Human rights challenges and other issues within the legal framework provided grounds for the National Assembly to initiate the enactment of new legislation. The Bill to strengthen Nigeria's public health system became eminent. The major apprehensions ${ }^{6}$ concerning the provisions of this Bill were Nigeria's outcry of adoption of other countries infectious disease Acts verbatim without taking lessons learnt from the pandemic in Nigeria and its effects on human rights. The emergency rules and laws became issues of litigations, as there were abuses on both the law and human rights by these emergency rules and laws that were in conflict with the 1999 Constitution. Also, the Nigerian Governors' forum rejected the proposed Control of Infectious Disease Bill, noting that it will take away their powers under the state and local governments.

Many Nigerians criticized the intent of the proposed Bill and requested that COVID-19 should be better looked at and treated under the Nigerian Quarantine Act for now, like Ebola, Cholera and Malaria that had existed in the past and further said, all these diseases are similar and have at one time of the other been declared an infectious disease.

\section{The Rule of Law and Evaluation of the Various Applicable Acts under Covid-19}

There is no gain saying that under the 1999 Constitution and the legal analysis of relevant emergency powers, the President ${ }^{7}$ can proclaim a state of emergency by an instrument published in the Official Gazette of the Government under any of the following conditions:

a) the federation is at war, or there is an imminent danger of invasion or involvement in a state of war; there is a breakdown of public order or public safety in part or the whole of the country.

b) there is a situation of imminent danger, public danger or disaster or natural calamity.

c) a state of emergency can be declared where the President receives a request from a state governor which is sanctioned by a majority in the House of Assembly.

The Constitution provides a closed list, which means it does not admit circumstances that are not listed. Abuse of emergency powers are one area where citizens get worried and would always refer to the Constitution. The Nigerian Constitution provides control on emergency powers. The legislature must approve any declaration by the President, the Senate and House of Representatives must immediately be informed after a declaration, to consider the situation and decide whether or not it should be ratified. ${ }^{8}$ If the legislative houses fail to pass a resolution approving the declaration, then such a declaration shall immediately cease to be implementable. ${ }^{9}$ However, the Nigerian Constitution provides for legislative awareness on the process of state of emergency. The Constitution authorizes certain emergency rights in as much as it is reasonably justifiable for the purpose of dealing with the situation that exists during the period of emergency. ${ }^{10}$ Citizens are aware and can revert to the judiciary to challenge if the declared emergency powers are required and eminent is necessary.

\footnotetext{
${ }^{1}$ https://www.bbc.com/news/world-africa-52317196. Accessed 4th September 2020.

${ }^{2} \mathrm{https}$ ://www.placng.org/situation room/sr/human-rights-concerns-mount-over-covid-19-measures/. Accessed 4th September 2020.

${ }^{3} \mathrm{https}: / /$ www.bbc.com/news/world-africa-52617551. Accessed 4th September 2020.

https://www.premiumtimesng.com/news/top-news/395296-amidst-covid-19-lockdown-nigeria-sees-increased-sexual-and-genderviolence.html. Accessed 4th September 2020

https://www.premiumtimesng.com/news/top-news/395296-amidst-covid-19-lockdown-nigeria-sees-increased-sexual-and-genderviolence.html. Accessed 4th September 2020

${ }^{6} \mathrm{https}$ ://nairametrics.com/2020/05/02/why-nigerians-ncdc-dg-are-opposed-to-the-new-ncdc-bill/. Accessed on $24^{\text {th }}$ September 2020 .

${ }^{7}$ Section 305 Part II of Chapter VII of the Nigerian constitution 1999 as amended.

${ }^{8}$ Section 305(2) Part II of Chapter VII of the Nigerian constitution 1999 as amended

${ }^{9}$ Section 305(6) Part II of Chapter VII of the Nigerian constitution 1999 as amended

${ }^{10}$ Section 45(2) Part II of Chapter VII of the Nigerian constitution 1999 as amended.
} 
Other boundaries regarding to human rights restrictions in times of emergency can also be derived from the International Covenant on Civil and Political Rights (ICCPR). ${ }^{1}$ First attempt to repeal Emergency Powers in Nigerian constitution was in $1961^{2}$ and subsequent bill in 2016. All these suffered setbacks because there were no plans and well thought out bill that can sail in the National Assembly at each attempt, rather citizens see these bills as mere copying and outright adoption of other countries infectious diseases Acts without aligning with Nigerian social, cultural and economic conditions.

Emergency powers have been used in several occasions in Nigeria in the past, especially for the purpose of reinstating peace in boundary conflicts and attacks. The most recent use of emergency power was in 2013 when former President Goodluck Jonathan ${ }^{3}$ declared a state of emergency in the whole of the North-Eastern Nigeria as a result of the attacks by a terrorist group called Boko Haram ${ }^{4}$ and emergency during the Ebola pandemic 2014. President Muhammed Buhari now using the emergency powers under section 305 of the Constitution for the purpose of restricting the COVID-19 pandemic is not out of place. However, both Ebola and COVID-19 situations based on notable authorities ${ }^{5}$ are not enough grounds for emergency or to warrant a declaration of state of emergency in a country like Nigeria, if we have a proper and functional health care system.

President Muhammadu Buhari used the existing emergency powers under the Infectious Diseases Law - the Quarantine. ${ }^{6}$ The Act gives the President comprehensive powers towards the preventing, introduction and spread in Nigeria, and the transmission from Nigeria, of dangerous infectious diseases and to make regulations for associated purposes. The President in line with the Act allotted the first COVID-19, 2020 Regulations, which declared the disease an infectious disease and proclaimed total national lockdown. This proclamation by the President generated legal disagreement: ${ }^{7}$ questions have been raised regarding the difference between the emergency powers under the Quarantine Act and those provided in section 305 of the Constitution. Both powers are different but tend to convey the same result. The President saw the loophole on the Quarantine Act and used it. It is important to note that a state of emergency is an exclusive process as recognized by the Constitution and this is different from the use of emergency powers under the regulations pursuant to the Quarantine Act of 1926. The constitution requires legislative approval after proclamation while under the Quarantine Act it is purely an executive function.

The rules issued by the President in line with the Quarantine Act suspends a lot of a human rights. It stipulates ${ }^{8}$ that inter and intra state movements in the concerned areas were prohibited for an initial period of 14 days and security agencies were instructed to strictly enforce the lockdown order. Citizens of the affected regions were to stay at home, COVID team to identify, trace and isolate infected persons. Certain groups of persons were exempted including people on essential duties such as medical workers and journalists. While the nation's seaports were to remain operational due to cargos, international boundaries closed along with airports (local and international). These unplanned rules inflicted pains and sufferings on people. Initial two weekly review were moved randomly so that citizens became disobedient and the law enforcement agents started compromising. States joined in putting their own state lockdowns alongside the federal one already imposed. All these constituted further infringements on human rights. Whereas, if perhaps we had a working health system, all these emergency laws and law of enforcement would have been unnecessary.

\section{Covid-19 Monitoring, the Applied Laws and Nigerian Experience}

At the onset of the panic emergency laws and enforcement, if well thought plans existed and the health system were working, perhaps, a better ideology would have taken place. Several issues arose on human rights and rule of law. The question now is all these imposed sacrifices are they indeed worthy for public health. Majority of Nigerian citizen still believe that COVID-19 is not real or even if real, is over flogged in its dimension, the restrictions became necessary but inflicted untold hardship on the ordinary citizens and may probably be a reason after a while they were several beaches and alternative ways were devised for survival by the citizens. The rules impacted upon the right to life as security agents enforcing the orders used this as an opportunity to extort and unjustifiably kill people. It was reported by the National Human Rights Commission that law enforcement agents

\footnotetext{
${ }^{1}$ Article 4 of the International Covenant on Civil and Political Rights (ICCPR) dated 16 December 1966; Accessed 24 ${ }^{\text {th }}$ September 2020.

${ }^{2}$ https://thenationonlineng.net/senate-emergency-powers-act-1961-repeal-bill/: Accessed 25 ${ }^{\text {th }}$ September 2020.

${ }^{3}$ Nigerian President from 5 May 2010 - 29 May 2015.

${ }^{4}$ Covid-19 and states of emergency (Nigerian Emergency (legal) responses to Covid-19: A worthy sacrifice for public health? by Dr. Likman

Abdulvant 18th May 2020. Accessed $26^{\text {th }}$ September 2020

${ }^{5}$ See item 33 reference above.

${ }^{6}$ Article 3; Presidential power to declare any place an infected local area: Nigerian Quarantine Act, dated 27th May, 1926.

7 On 2nd April 2020; Lawyers divided over president's power to invoke State of Emergency, Quarantine Act; available at: https://www.vanguardngr.com/2020/04/covid-19-lawyers-divided-over-presidents-power-to-invoke-state-of-emergency-quarantine-act/; Accessed on $27^{\text {th }}$ September 2020.

${ }^{8}$ National broadcast by President Mohammed Buhari on COVID-19 dated 29 ${ }^{\text {th }}$ March 2020: https://nairametrics.com/2020/03/29/presidentmuhammadu-buharis-full-speech-on-covid-19-pandemic/ Accessed on $27^{\text {th }}$ September 2020.
} 
had killed more than seventeen people during the lockdown in several incidents of extrajudicial killings, ${ }^{1}$ as well as series of punishments inflicted on people who violated lockdown orders. Furthermore, lockdowns increased cases of domestic violence across the Country, as a lot of marriages experienced breakdown while our courts were shut down and culprits got away unpunished. This is indeed a huge challenge to the nation at large considering the insecurity and hardship meted on the citizen by government and world economy before the pandemic. The COVID19 rules also affected freedom of worship since restrictions on gathering for religious purposes was imposed. All these necessitated the Amnesty International ${ }^{2}$ to issue caution to government agencies to respect human rights and give clear instructions to security agencies not to abuse their powers. To prevent the spread of COVID-19, NCDC expanded the role of police, paramilitary and armed forces to not only uphold pre-existing laws but to also enforce new public health enforcement directives.

\section{Recommendation}

Based on what happened during the COVID-19 pandemic in Nigeria and how the government grappled with the emergency laws and law enforcement application, which ended up in confusion, litigation and nation-wide criticism, it is advised that we take learnings on the ineffectiveness and dilapidated Nigerian health sector system, conditions of our hospitals and general lesson learnt within this period. Also, how the citizens felt in the management of COVID-19, as well as stock knowledge on the Nigerian Quarantine Act of 1926, Nigeria Centre for Diseases Control and Prevention Act and Nigerian 1999 Constitution in the call for public debate on revamping the Nigerian Health sector. New initiative would be to collect legal documents from the coronavirus responses and learn from the laws that were implemented for appropriate constitutional review

Furthermore, Nigerian legislators should initiate review of 1999 constitution to accommodate and harmonize the ethnics of Nigerian Quarantine Act of 1926, Nigeria Centre for Diseases Control and Prevention and Act and Nigerian 1999 Constitution on health and infectious disease control.

In a nutshell, Nigerian health system should be given upmost priority and under the exclusive list in the Constitution. Furthermore, emergency should be declared in the Nigerian health sector now, to align with best world standard and practices, to rebuild confidence in the citizenry. One good lesson got from COVID-19 pandemic is that both the poor and rich were all confined and forced to use the Nigerian health system since our independence 1960, which afforded the citizens the opportunity to know that our health sector needed serious upgrading and re-trainings of our health personnel's. Also, capital flight on health treatment cost abroad were saved in terms of foreign exchange.

\section{Conclusion}

The legal enforcement of coronavirus restrictions serves as a reminder of how the law can help or hinder the public health response. The various Infectious Diseases Acts in Nigeria should be harmonized and updated based on experiences, lessons learnt and the management of COVID-19. In such emergency situations, the human rights of Nigerians citizens should be guided and protected in line with best global standards and practices.

\footnotetext{
1 On $16^{\text {th }}$ April 2020 BBC reported that Nigerian Security forces have kill more Nigerians than Covid-19, available at: https://www.bbc.com/news/world-africa-52317196; Accessed $26^{\text {th }}$ September 2020.

${ }^{2}$ On 1st April 2020; Osai Ojigho, Director of Amnesty International Nigeria issued a note that Nigerian Authorities must uphold human rights in fight to curb COVID-19; available at: https://www.amnesty.org/en/latest/news/2020/04/nigeria-covid-19/: Accessed 26 ${ }^{\text {th }}$ September 2020 .
} 